\title{
Hubungan Pengetahuan dan Sikap Ibu dengan Pemberian Asi Eksklusif
}

\author{
Andi Herman ${ }^{a}$, Mustafa ${ }^{a}$, Saida $^{a}$, Wa Ode Chalifa ${ }^{b}$

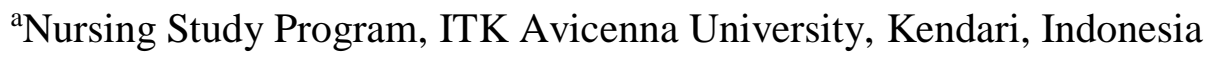 \\ ${ }^{b}$ Fakultas Kedokteran, Universitas Haluoleo, Kendari, Indonesia
}

Email Korespondensi: andi.herman0905@gmail.com

\begin{abstract}
Introduction: The best way to maintain health of a baby and a mother is by giving exclusive breastfeeding for at least 6 months. The life expectancy of the baby will increase to $22 \%$ if the baby receives breast milk within the first one hour of birth. The purpose of the study was to determine the correlation of mother's knowledge and attitudes with exclusive breastfeeding. Methods: This research is an analytic research with cross-sectional approach. It was conducted at Abeli Health Center in Kendari City. The population of all mothers who have babies aged 7-12 months were 93 mothers. The sampling technique used was total sampling. Data were processed by using univariate and bivariate analysis. Results: The results showed there was correlation between mothers' knowledge and exclusive breastfeeding with value ( $p$ $=0.003<a=0.05)$, there was correlation between mothers' attitude and exclusive breastfeeding and value ( $p=0.019<a=0.05)$, and there was correlation between mothers' actions and exclusive breastfeeding with value $(p=0.006<a=0.05)$. Conclucion: The study concluded that there was correlation of mothers' knowledge, attitudes, and actions with giving exclusive breastfeeding to infants.
\end{abstract}

Keywords: Attitudes, Exclusive Breastfeeding, Knowledge.

\begin{abstract}
Abstrak
Pendahuluan: Langkah terbaik menjaga kesehatan bayi dan ibunya adalah pemberian ASI eksklusif setidaknya sampai 6 bulan. Angka harapan hidup bayi akan meningkat menjadi 22\% jika bayi disusui pada 1 jam pertama setelah kelahiran. Tujuan penelitian untuk mengetahui hubungan pengetahuan dan sikap ibu dengan pemberian ASI eksklusif. Metode: Jenis penelitian yang analitik dengan pendekatan cross sectional. Penelitian ini dilakukan di Puskemas Abeli Kota Kendari. Populasi seluruh ibu yang memiliki bayi usia 7-12 bulan dengab jumlah $93 \mathrm{ibu}$. Tehnik pengambilan sampel yaitu total sampling. Data diolah secara univariat dan bivariat. Hasil: Hasil penelitian menunjukan ada hubungan antara Pengetahuan Ibu dengan pemberian ASI eksklusif dengan nilai $(p=0,003<a=0,05)$. Terdapat hubungan Sikap Ibu dengan pemberian ASI eksklusif dengan nilai $(p=0,019<a=0,05)$. Dan ada hubungan antara Tindakan Ibu dengan pemberian ASI eksklusif dengan nilai $(p=0,006<a=$ 0,05). Kesimpulan: Kesimpulan bahwa terdapat hubungan antara Pengetahuan, Sikap dan Tindakan Ibu dengan pemberian ASI eksklusif kepada Bayi.
\end{abstract}




\section{PROFESIONAL HEALTH JOURNAL}

Volume 2, No. 2, Juni 2021 (Hal. 84-89)

Available Online at https:// http://jurnal.stikesbanyuwangi.ac.id

Kata kunci: pengetahuan, Sikap, Pemberian ASI

\section{PENDAHULUAN}

Air Susu Ibu (ASI) merupakan makanan terbaik dan alamiah untuk bayi. Menurut Arlene Eisenberg ASI adalah makanan alamiah yang disediakn untuk bayi, sehingga mempunyai komposisi nutrisi yang sesuai umtuk perkembangan bayi sehat. ASI merupakan suatu proses alamiah, namun sering ibu-ibu tidak berhasil menyusui atau menhentikan menysusui dari yang semestinya (Dahlan, Mubin, and Mustika 2013).

World Health Organization (WHO) merekomendasikan bahwa langkah terbaik menjaga kesehatan bayi dan ibunya adalah pemberian ASI eksklusif setidaknya sampai 6 bulan. ASI eksklusif bukan hanya semata didasarkan pada pertimbangan bahwa ASI eksklusif adalah makanan terbaik bagi bayi, akan tetapi juga menjadi bagian integral dari proses reproduksi yang memiliki implikasi penting bagi kesehatan ibu yang menyusui. Dan pemberian ASI selama 6 bulan justru mendorong pertumbuhan bayi yang optimal (Maryunani, 2012)

Suatu penelitian Ambarwati, Muis, and Susanti (2013), menunjukan bahwa $16 \%$ kematian bayi baru lahir bisa di cegah bila bayi di susui pada hari pertama kelahiran. Angka harapan hidup bayi akan meningkat menjadi $22 \%$ jika bayi disusui pada 1 jam pertama setelah kelahiran. Pemberian ASI dapat mengurangi resiko terkena penyakit kencing manis, kanker pada anak dan dapat mengurangi kemungkinan penyakit jantung (Roesli 2012). Selain itu ASI juga dapat melindungi bayi dari penyakit diare, infeksi telinga, insfeksi kandung kemih, eksema, diabetes, infeksi paru-paru dan kegemukan (Maryunani 2012). Sedangkan anak yang tidak di beri ASI secara eksklusif akan lebih cepat terjangkit

penyakit kronis seperti kanker, jantung, Hipertensi dan diabetes setelah dewasa (Dahlan, Mubin, and Mustika 2013)

Dewasa ini di Indonesia $80-90 \%$ para ibu di daerah pedesaan masih menyusui bayinya sampai umur lebih dari satu tahun, tetapi dikota-kota ASI sudah banyak diganti dengan susu formula. Hal ini dipengaruhi oleh beberapa faktor yang menyebabkan rendahnya bayi mendapat ASI ekslusif (Damayanti 2015).

Pertumbuhan anak bersusu formula tak semutu anak ber-ASI. Anak tumbuh kurang normal, dapat lebih kecil atau bahkan lebih besar. Jika pemakaian susu formula tidak menurut aturan, anak menjad ikurus. Jika terlalu banyak susu formula atau anak akan menjadi gemuk (Maryunani 2012).

Pengetahuan mempengaruhi pola pikir seseorang dalam menerima informasi, bila pengetahuan seseorang cukup maka pola pikir seseorang akan lebih luas dan daya tangkap dalam menerima informasi akan lebih terbuka. Sedangakan sikap seseorang dipengaruhi oleh pengetahuan. sikap negatifnya terhadap ASI jika pengetahuan tentang hal itu kurang (Pradany and Margawati 2015).

\section{METODE}

Jenis penelitian ini adalah penelitian analitik dengan pendekatan cross sectional. dilakukan Wilayah Kerja Puskesmas Abeli Kota Kendari. Jumlah Sampel penelitian sebanyak 93 ibu yang mempunyai bayi umur 7-12 bulan. Tehnnik pengambilan sampel secara accidental total. Data diolah secara univariat dan bivariat. 


\section{PROFESIONAL HEALTH JOURNAL}

Volume 2, No. 2, Juni 2021 (Hal. 84-89)

Available Online at https:// http://jurnal.stikesbanyuwangi.ac.id

HASIL

Tabel 1. Pemberian ASI ekslusif Pada Bayi

\begin{tabular}{|c|c|c|c|c|c|}
\hline \multirow{3}{*}{ Variabel } & \multicolumn{4}{|c|}{ Pemberian ASI eksklusif } & \multirow{3}{*}{$\begin{array}{c}p \\
\text { value }\end{array}$} \\
\hline & \multicolumn{2}{|c|}{$\mathrm{Ya}$} & \multicolumn{2}{|c|}{ Tidak } & \\
\hline & $\mathrm{n}$ & $\%$ & $\mathrm{n}$ & $\%$ & \\
\hline \multicolumn{6}{|l|}{ Pengetahuan } \\
\hline Cukup & 27 & 29 & 15 & 16,1 & \multirow{2}{*}{0,003} \\
\hline Kurang & 17 & 18,3 & 34 & 36,6 & \\
\hline \multicolumn{6}{|l|}{ Sikap } \\
\hline Cukup & 25 & 26,9 & 16 & 17,2 & \multirow{2}{*}{0,019} \\
\hline Kurang & 19 & 20,4 & 33 & 35,5 & \\
\hline
\end{tabular}

Tabel diatas terlihat bahwa hasil analisis hubungan antara pengetahuan dengan pemberian ASI eksklusif pada bayi menunjukan bahwa dari 93 responden yang memiliki pengetahuan cukup dan memberikan ASI eksklusif terdapat 27 responden $(29,0 \%)$ dan yang memiliki pengetahuan cukup tapi tidak memberikan ASI eksklusif terdapat 15 respoden $(16,1 \%)$. Sedangkan responden yang memiliki pengetahuan kurang dan memberikan ASI eksklusif terdapat 17 responden $(18,3 \%)$ dan yang memiliki pengetahuan kurang tapi tidak memberikan ASI eksklusif terdapat 34 responden $(36,6 \%)$. Hasil uji statistik diperoleh nilai $\rho$ value: 0,003 lebih kecil dari nilai $a=0,05$. Sikap ibu dengan pemberian ASI ekslusif pada bayi menunjukan bahwa dari 93 responden terdapat 25 responden $(26,9 \%)$ yang memiliki sikap cukup dan memberikan ASI eksklusif dan terdapat 16 responden $(17,2 \%)$ memiliki sikap cukup tapi tidak memberikan ASI eksklusif. Sedangkan responden yang memiliki pengetahuan kurang dan memberikan ASI eksklusif terdapat 19 responden $(20,4 \%)$ dan 33 responden $(35,5 \%)$ yang memiliki sikap kurang dan tiak pemberikan ASI eksklusif. Hasil uji statistik diperoleh nilai $\rho$ value: 0,019 lebih kecil dari nilai $a=$ 0,05 .

\section{PEMBAHASAN}

Pengetahuan merupakan unsur pengisi akal dan jiwa seseorang yang sadar dan secara nyata terkandung dalam otaknya. Dalam kamus bahasa Indonesia dijelaskan bahwa pengetahuan atau tahu adalah mengerti setelah melihat, menyaksikan dialami atau diajar (Azwar 2010). Hasil penelitia menunjukkan adanya kecenderungan bahwa pada ibu yang tingkat pengetahuannya baik tentang ASI Eksklusif, cenderung memberikan ASI eksklusif dari pada ibu yang pengetahuannya tidak baik. Hal ini terlihat bahwa ibu yang kategori pengetahuannya kurang sebanyak $34 \mathrm{ibu}$ (36,6\%) yang tidak memberikan ASI eksklusif dengan pengetahuan kurang lebih banyak yaitu berjumlah $49 \mathrm{ibu}$ $(52,7 \%)$, dibandingkan dengan yang memiliki pengetahuan baik hanya terdapat $15 \mathrm{ibu}(16,1 \%)$, sedangkan pada ibu yang tingkat pengetahuan baik akan cenderung memberikan ASI eksklusif, dimana hasil penelitian menunjukan sebanyak 44 ibu (47,3\%) yang memberikan ASI ekslusif diantaranya mempunyai pengetahuan baik lebih banyak yaitu berjumlah 27 ibu $(29,0 \%)$ dan $17 \mathrm{ibu}(18,3 \%)$ yang mempunyai pengetahuan kurang.

Penelitian ini sejalan dengan penelitian Budiyanto, Asti, and Yuwono (2015), tentang hubungan pengetahuan dengan pemberian asi eksklusif dikelurahan gunung pati kota semarang tahun 2011 terhadap 38 sampel, dimana hasil penelitian menunjukkkan bahwa ada hubungan antara pengetahuan ibu dengan pemberian ASI eksklusif di Kelurahan Gunung pati Kota Semarang dengan nilai $\mathrm{p}$ value 0,028 . Dimana didapatkan data bahwa sebagian besar responden dengan 


\section{PROFESIONAL HEALTH JOURNAL}

Volume 2, No. 2, Juni 2021 (Hal. 84-89)

Available Online at https:// http://jurnal.stikesbanyuwangi.ac.id

pengetahuan kurang yaitu $(55,3 \%)$ dan yang mempunyai pengetahuan baik $(44,7 \%)$.

Hasil penelitian ini sejalan dengan teori yang menyatakan bahwa pengetahuan atau kognitif merupakan domain yang sangat penting dalam membentuk tindakan seseorang. Dari pengalaman dan penelitian terbukti bahwa perilaku yang didasari oleh pengetahuan lebih langgeng daripada perilaku yang tidak didasari pengetahuan. Hal ini sejalan pula dengan teori Green bahwa perilaku dipengaruhi oleh 3 faktor utama dimana salah satu faktor predisposisi yang ada di dalamnya pengetahuan seseorang (Azwar 2010)

Peran seorang ibu dalam memberikan ASI eksklusif pada bayinya sangatlah penting. Karenanya suatu pemahaman tentang program ini amat diperlukan untuk kalangan tersebut. Pemahaman ibu atau pengetahuan ibu terhadap ASI eksklusif sangat dipengaruhi oleh tingkat pendidikan ibu (Listyo 2015).

Pengetahuan yang kurang tentang ASI eksklusif bisa menjadi faktor kurangnya pemberian ASI eksklusif pada bayi. Hal ini dikuatkanoleh penelitian yang dilakukan (Listyo 2015) yang mengungkapkan bahwaperilaku yang didasari oleh pengetahuan akan lebih langgeng daripada perilaku, yang tidak didasari pengetahuan (Notoatmodjo 2011). Pengetahuan ibu tentang ASI eksklusif dapat mempengaruhi ibu dalammemberikan ASI eksklusif. Semakin baik pengetahuan Ibu tentang manfaat ASIeksklusif, maka seorang ibu akan memberikan ASI eksklusif pada anaknya.Begitu juga sebaliknya, semakin rendah pengetahuan ibu tentang manfaat ASIeksklusif, maka semakin sedikit pula peluang ibu dalam memberikan ASIeksklusif (Ermianti, Irmayani, and Latief 2014)
Pengetahuan ibu tentang ASI eksklusif sangat penting, karena pengetahuan memiliki hubungandengan tindakan pemberian ASI ekslusif.Ibu yang memiliki pengetahuan baik di Wilayah Puskesmas Abeli lebih cenderung melakukan tindakan pemberian ASI ekslusif dibandingkan dengan Ibu dengan penegtahuan yang kurang, karena memiliki pemahaman yang baik akan pentingnya tindakan tersebut, selain karena sebagian besar ibu sudah mendapatkan informasi didukung oleh kematangan cara berpikirakan pemilihan sesuatu yang menurutnya baik (Ermianti, Irmayani, and Latief 2014).

Sikap merupakan kesiapan untuk bereaksi terhadap suatu objek dengan caracara tertentu, kesiapan dimaksud merupakan kecenderungan potensial untuk bereaksi dengan cara tertentu apabila individu dihadapkan pada suatu stimulus yang menghendaki adanya respons (Azwar 2010). Sikap dapat terbentuk dari adanya interaksi sosial yang dialami individu. Interaksi di sini tidak hanya berupa kontak sosial dan hubungan antar pribadi sebagai anggota kelompok sosial, tetapi meliputi juga hubungan dengan lingkungan fisik maupun lingkungan psikologis sekitarnya (Ermianti, Irmayani, and Latief 2014).

Berdasarkan hasil bivariat menunjukan bahwa hasil analisis hubungan antara sikap dengan pemberian ASI eksklusif diperoleh bahwa ada sebanyak 44 ibu $(47,3 \%)$ yang memberikan ASI eksklusif diantaranya mempunyai sikap cukup 25 ibu $(26,9 \%)$ dan yang mempunyai sikap kurang 19 ibu $(20,4 \%)$. Sedangkan yang tidak memberikan ASI eksklusif sebanyak 49 ibu $(52,7 \%)$ diantaranya mempunyai sikap cukup 16 ibu $(17,2 \%)$ dan yang mumpunyai sikap kurang sebanyak 33 ibu (35,5\%). Hasil uji statistik hubungan antara variabel sikap dengan pemberian ASI eksklusif pada bayi 


\section{PROFESIONAL HEALTH JOURNAL}

Volume 2, No. 2, Juni 2021 (Hal. 84-89)

Available Online at https:// http://jurnal.stikesbanyuwangi.ac.id

di Wilayah Kerja Puskesmas Abeli dengan nilai $\rho$ value Hasil penelitian ini sejalan dengan penelitian Rachmaniah (2014), hasil penelitian menunjukkan bahwa faktor sikap mempunyai pengaruh yang bermakna terhadap perilaku pemberian ASI eksklusif dimana didapatkan nilai ( $\mathrm{p}=0.006, \mathrm{OR}=2.81, \mathrm{CI} 95 \%)$.

Sikap diperoleh lewat pengalaman sehingga akan menimbulkan pengaruh langsung terhadap perilaku. Pengaruh langsung tersebut lebih berupa perilaku yang akan direalisasikan hanya apabila kondisi dan situasi yang memungkinkan. Dalam interaksi ini individu membentuk pola sikap tertentu terhadap objek yang dihadapinya (Ermianti, Irmayani, and Latief 2014).

Sikap Ibu tentang pemberian ASI eksklusif merupakan faktor yang menentukan seseorang untuk bersedia atau kesiapan dalam memberikan ASI secara eksklusif, sikap ibu adalah bagaimana reaksi atau respon ibu menyusui terhadap Asi esklusif Jika ibu sudah memiliki sikap yang kuat dalam memberikan ASI eksklusif, maka perilakunya menjadi lebih konsisten dalam memberikan ASI eksklusif (Ermianti, Irmayani, and Latief 2014).

Sikap sangat berpengaruh pada perilaku ibu dalam memberikan ASI esklusif pada bayinya. Hal ini sejalan dengan penelitian yang dilakukan oleh (Purnamasari and Mufdlilah 2015) bahwa ada hubungan antara sikap dengan pemberian ASI esklusif. Ibu yang memiliki sikap yang kurang atau tidak tanggap dalam pemberian pemberian ASI eksklusif, dapat memperbesar risiko atau kemungkinan bayi yang tidak mendapatkan ASI eksklusif. Pengkuruan sikap dapat dilakukan dengan menilai pernyataan sikap seseorang tentang pemberian ASI eksklusif. Pernyataan sikap adalah rangkaian kalimat yang menyatakan sesuatu mengenai obyek sikap yang hendak diungkap.

Sikap merupakan faktor yang yangberhubungan dengan pemberian ASIekslusif, karena sikap merupakan reaksitertutup jika ibu sudah memiliki sikapyang positive sejak awal maka tindakanyang dilaksanakan sangat konsisten danbertanggung jawab. Sikap dipengaruhioleh bentuk ketertarikan terhadap sesuatudan pangalaman yang ada dilingkungansekitar serta pandangan dari orang yangdiyakini dan dipercaya (Sarina, Amiruddin, and Darlian 2017).

\section{KESIMPULAN DAN SARAN}

Ada hubungan pengetahuan, dan sikap dengan pemberian ASI ekslusif pada bayi di Wilayah Kerja Puskesmas Abeli dengan nilai $\rho$ value $<a=0,05$. Meningkatkan pengetahuan Ibu tentang manfaat ASI Esklusif akan bersikap positif terhadap pemebrian ASI ke Anaknya 1-6 bulan.

\section{DAFTAR PUSTAKA}

Ambarwati, Ria, Siti Fatimah Muis, and Purwanti Susanti. 2013. 'Pengaruh Konseling Laktasi Intensif Terhadap Pemberian Air Susu Ibu (ASI) Eksklusif Sampai 3 Bulan'. Jurnal Gizi Indonesia (The Indonesian Journal of Nutrition) 2(1).

Azwar, Saifuddin. 2010. 'Tes Prestasi: Fungsi Dan Pengembangan Pengukuran Prestasi Belajar'.

Budiyanto, B, Arnika Dwi Asti, and Podo Yuwono. 2015. 'Hubungan Ketersediaan Fasilitas Penunjang Terhadap Keberhasilan Pemberian ASI Eksklusif Pada Ibu Yang Bekerja Sebagai Tenaga Kesehatan'. Jurnal Ilmiah Kesehatan Keperawatan 11(1). 


\section{PROFESIONAL HEALTH JOURNAL}

Volume 2, No. 2, Juni 2021 (Hal. 84-89)

Available Online at https:// http://jurnal.stikesbanyuwangi.ac.id

Dahlan, Arvina, Fatkhul Mubin, and Dian Nintyasari Mustika. 2013. 'Hubungan Status Pekerjaan Dengan Pemberian Asi Eksklusif Di Kelurahan Palebon Kecamatan Pedurungan Kota Semarang'. Jurnal Kebidanan 2(2): 56-60.

Damayanti, Dini Fitri. 2015. 'Tumbuh Kembang Bayi 0-6 Bulan Menurut Status ASI Di Puskesmas Telaga Biru Pontianak'. Jurnal vokasi kesehatan 1(3): 75-79.

Ermianti, Ermianti, Irmayani Irmayani, and Burhanuddin Latief. 2014. 'FaktorFaktor Yang Mempengaruhi Pemberian Air Susu Ibu (Asi) Eksklusif Pada Bayi Di Wilayah Kerja Puskesmas Mandalle Kab. Pangkep'. Jurnal Ilmiah Kesehatan Diagnosis 5(1): 41-46.

Listyo, Melissa Ivana. 2015. 'Gambaran Pemberian ASI Terhadap Insiden Dermatitis Atopik Pada Usia 0-2 Tahun Di Klinik Gotong Royong Surabaya Bulan Juni-Agustus 2015'.

Maryunani, Anik. 2012. 'Inisiasi Menyusui Dini, ASI Eksklusif Dan Manajemen Laktasi'. Jakarta: Trans Info Media.

Notoatmodjo, Sukidjo. 2011. 'Ilmu \& Seni Kesehatan Masyarakat'. Jakarta. Rineka Cipta.

Pradany, Shohifah Putri, and Ani Margawati. 2015. 'Hubungan Antara Tingkat Kehadiran Ibu Di Kelas Ibu Hamil Dengan Perilaku Pemberian ASI Eksklusif'.

Purnamasari, Desi, and Mufdlilah Mufdlilah. 2015. 'Faktor-Faktor Yang Berhubungan Dengan

Ketidakberhasilan ASI Eksklusif Di Wilayah Kerja Puskesmas Pakualaman Kota Yogyakarta'.

Andi Herman dkk, Hubungan Pengetahuan dan Sikap Ibu Dengan Pemberian Asi Eksklusif
Rachmaniah, Nova. 2014. 'Hubungan Tingkat Pengetahuan Ibu Tentang ASI Dengan Tindakan ASI Eksklusif'.

Roesli, Utami. 2012. Panduan: Inisiasi Menyusu Dini: Plus Asi Eksklusif. Pustaka Bunda.

Sarina, Sarina, Amiruddin Amiruddin, and Lili Darlian. 2017. 'Faktor-Faktor Yang Berhubungan Dengan Lama Pemberian Asi Eksklusif Pada Bayi (0-6 Bulan) Di Wilayah Kerja Puskesmas Mokoau Kota Kendari'. Jurnal Ampibi (Almuni Pendidikan Biologi) 2(1). 